\title{
Penerapan Model Pembelajaran Little Step Dengan Studi Kasus Pembelajaran Materi Linear Programming Metode Grafik
}

\author{
Vina Anggraeni, Leony Lidya, Sandhika Galih Amalga \\ Jurusan Teknik Informatika, Fakulstas Teknik \\ Universitas Pasundan \\ Jl. Dr. Setiabudhi no.193 \\ vina.0740133@gmail.com, \\ leonylidya@yahoo.com, sandhikagalih@unpas.ac.id
}

\begin{abstract}
ABSTRAK
Tingkat pemahaman dan kemampuan peseta didik yang mengikuti proses belajar mengajar cenderung variatif. Hal tersebut menjadi kendala khususnya pada proses belajar mengajar yang menggunakan metode konvensional (metode ceramah). Oleh sebab itu, model pembelajaran banyak dikembangkan. Salah satu pengembangan model pembelajaran untuk menjawab tantangan tersebut adalah little step. Model Pembelajaran Little Step adalah sistem belajar yang memberikan program belajar secara perseorangan sesuai dengan kemampuan masing-masing, yang memungkinkan siswa menggali potensi dirinya dan mengembangkan kemampuannya secara maksimal. Tujuan dari makalah ini adalah merancang model pembelajarn Little step untuk pembelajaran materi Linear Programming dalam pemecahan persoalan linear programming menggunakan metode grafik berupa diagram pohon pengetahuan, tangga materi, road map, dan lembar kerja untuk pembelajaran materi Linear Programming metode grafik. Berdasarkan hasil analisis dapat ditarik kesimpulan bahwa rancangan model pembelajaran Little step yang dibuat, seperti pembuatan diagram pohon pengetahun, tangga materi, road map pembelajaran materi Linear Programming dalam pemecahan persoalan linear programming menggunakan metode grafik. Road map tersebut dapat dijadikan acuan untuk pembelajaran materi linear programming metode grafik, rancangan model pembelajaran ini menghasilkan lembar kerja materi pembelajaran Linear Programming metode grafik yang dibuat secara Little Step. Kemudian dari analisis yang telah dilakukan maka dibangunlah perangkat lunak untuk menunjang proses belajar mengajar model pembelajaran Little Step yang berfungsi untuk wadah sharing informasi, download materi, download lembar kerja, kontak dan pengumuman laporan perkembangan mahasiswa berdasarkan pencapaian masing-masing mahasiswa.
\end{abstract}

Kata kunci: Little Step, Linear Programming, lembar kerja, pengujian

\section{Pendahuluan}

Indikator yang memengaruhi kualitas pendidikan adalah standar kualitas pendidikan yang menurut DIKTI terdiri dari 10 indikator antara lain proses 
pembelajaran, kurikulum program studi, sumber daya manusia, kemahasiswaan, prasarana dan sarana, suasana akademik, keuangan, penelitian dan publikasi, pengabdian pada masyarakat dan tata kelola. Salah satu indikator yang disebutkan diatas yaitu proses pembelajaran. Proses pembelajaran selama ini menggunakan metode konvensional yaitu metode ceramah. Metode ceramah ini dilakukan dengan cara menyampaikan materi pelajaran kepada peserta didik secara langsung atau dengan cara lisan. Tingkat pemahaman dan kemampuan peserta didik yang mengikuti proses belajar mengajar cenderung bervariatif. Hal tersebut menjadi kendala khususnya pada proses mengajar yang menggunakan metode konvensional.

Berdasarkan permasalahan tersebut, penulis menerapkan model alternatif untuk mengatasi rendahnya mutu pendidikan, yaitu dengan model pembelajaran yang berpusat pada siswa.

Fokus penelitian adalah mengembangkan model pembelajaran Little Step dengan studi kasus materi Linear Programming metode grafik, mengevaluasi hasil pembelajaran Little Step pada materi Linear Programming metode grafik, dan model tool yang dapat digunakan yaitu perangkat lunak berbasis web agar memudahkan dalam sharing informasi.

Penelitian bertujuan untuk merancang model pembelajaran Little Step seperti membuat diagram pohon pengetahun, tangga materi, road map, pembelajaran materi Linear Programming dalam pemecahan persoalan linear programming menggunakan metode grafik, dan lembar kerja yang dibuat secara little step serta membuat perangkat lunak untuk menunjang kebutuhan model pembelajaran little step. Penunjang kebutuhan yang dimaksud adalah media berbagi materi pembelajaran, bertanya kepada dosen dan evaluasi pembelajaran.

\section{Model dan Pendekatan Pembelajaran}

\section{Landasan Teori}

Model Pembelajaran dapat diartikan sebagai bingkai dari pendekatan pembelajaran, strategi pembelajaran, metode pembelajaran, teknik dan taktik pembelajaran. Seperti yang dikemukakan oleh Sudrajat "Apabila antara pendekatan, strategi, metode, teknik dan bahkan taktik pembelajaran sudah terangkai menjadi satu kesatuan yang utuh maka terbentuklah apa yang disebut dengan model pembelajaran. Jadi, model pembelajaran pada dasarnya merupakan bentuk pembelajaran yang tergambar dari awal sampai akhir yang disajikan secara khas oleh guru. Dengan kata lain, model pembelajaran merupakan bungkus atau bingkai dari penerapan suatu pendekatan, metode, dan teknik pembelajaran". [SUD08]

Pendekatan pembelajaran dapat diartikan sebagai titik tolak atau sudut pandang kita terhadap proses pembelajaran, yang merujuk pada pandangan tentang terjadinya suatu proses yang sifatnya masih sangat umum, di dalamnya mewadahi, menginsiprasi, menguatkan, dan melatari metode pembelajaran dengan cakupan teoretis tertentu. Dilihat dari pendekatannya, pembelajaran terdapat dua jenis pendekatan, yaitu: pendekatan pembelajaran yang berorientasi atau berpusat 
pada siswa (student centered approach) dan pendekatan pembelajaran yang berorientasi atau berpusat pada guru (teacher centered approach). [SUD08]

1. Pendekatan Expository, menekankan pada penyampaian informasi yang disampaikan sumber belajar kepada warga belajar.

2. Pendekatan Inquiry, ditujukan kepada cara belajar yang menggunakan cara penelaahan atau pencarian terhadap sesuatu objek secara kritis dan analitis, sehingga dapat membentuk pengalaman belajar yang bermakna.

\section{Strategi, Metode, Teknik dan Taktik Pembelajaran}

Strategi pembelajaran sifatnya masih konseptual dan untuk mengimplementasikannya digunakan berbagai metode pembelajaran tertentu. Dengan kata lain, strategi merupakan "a plan of operation achieving something" sedangkan metode adalah "a way in achieving something" [Wina Senjaya 08)].

Berdasarkan yang dikemukanan oleh Wina Senjaya (2008) "a plan of operation achieving something" sedangkan metode adalah "a way in achieving something". Terdapat beberapa metode pembelajaran yang dapat digunakan untuk mengimplementasikan strategi pembelajaran. Beberapa metode mengajar [ASY12]:
1. Metode Ceramah (Preaching Method)
2. Metode diskusi (Discussion method)
3. Metode demontrasi (Demonstration method)
4. Metode Ceramah Plus
5. Metode Resitasi (Recitation Method)
6. Metode Percobaan (Experimental Method)
7. Metode Karya Wisata
8. Metode Latihan Keterampilan (Drill Method)
9. Metode Mengajar Beregu (Team Teaching Method)
10. Metode Mengajar Sesama Teman (Peer Teaching Method)
11. Metode Pemecahan Masalah (Problem Solving Method)
12. Metode Perancangan ( Project Method)
13. Metode Bagian ( Teileren Method)
14. Metode Global (Ganze method)
15. Metode Discovery
16. Metode Inquiry

Metode pembelajaran dijabarkan ke dalam teknik dan gaya pembelajaran. Dengan demikian, teknik pembelajaran dapat diatikan sebagai cara yang dilakukan seseorang dalam mengimplementasikan suatu metode secara spesifik [SUD08]. Sedangkan taktik pembelajaran merupakan gaya seseorang dalam melaksanakan metode atau teknik pembelajaran tertentu yang sifatnya individual [SUD08]. Berikut dijelaskan melalui gambar hubungan antara model pembelajaran, strategi pembelajaran, metode pembelajaran, teknik dan taktik. 


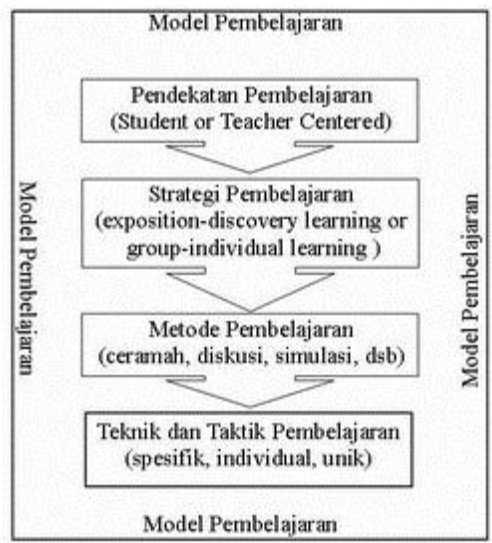

Gambar 1. Hirarki model, pendekatan, strategi, metode pembelajaran, teknik dan taktik

\section{Model Pembelajaran Little Step}

Little Step adalah sistem belajar yang memberikan program belajar secara perseorangan sesuai dengan kemampuan masing-masing, yang memungkinkan siswa menggali potensi dirinya dan mengembangkan kemapuannya secara maksimal [KUS11]. Model Pembelajaran Little Step ini cocok dengan menggunakan pendekatan pembelajaran yang berorientasi atau berpusat pada siswa (student centered approach), karena model ini menuntut peserta didik untuk belajar mandiri dan memecahkan masalahnya sendiri. Pendekatan yang berorieontasi pada siswa yaitu pendekatan Inkuiri.

Pendekatan Inkuiri dalam pembelajaran lebih berpusat pada keaktifan warga belajar. Dalam kegiatan pembelajaran dengan menggunakan pendekatan. Model Pembelajaran Little Step ini diadopsi dari kumon. Berikut akan dipaparkan beberapa metode dan teori pendukung model pembelajaran Little Step.[KUS11]

\section{Penelitian Operasional}

Definisi 1. Sebagai aplikasi metode-metode, teknik-teknik, dan peralatan-peralatan ilmiah dalam menghadapi masalah-masalah yang timbul di dalam perusahaan dengan tujuan ditemukannya pemecahan yang optimum.

(Churman, Arkoff dan Arnoff)

\section{Linear Programming}

Program linear yang diterjemahkan dari Linear Programming (LP) adalah suatu cara untuk menyelesaikan persoalan pengalokasian sumber-sumber yang terbatas diantara beberapa aktivitas yang bersaing., dengan cara yang terbaik yang mungkin dilakukan. [DIM92].

\section{Teknik Pemecahan Model Program Linear}

Pada dasarnya, metode-metode yang dikembangkan untuk memecahkan model pemrograman linear ditunjukan untuk mencari solusi dari beberapa alternatif 
solusi yang dibentuk oleh persamaan pembatas sehingga diperoleh nilai fungsi tujuan yang optimum.

Ada dua cara yang bisa digunakan untuk menyelesaikan persoalan-persoalan pemrograman linear ini, yaitu dengan cara grafis dan metode simplex [DIM92]. Terdapat 4 jenis solusi yang bisa dihasilkan dengan menggunakan metode grafik, yaitu:

1. Optimal Solution/Unique Solution, merupakan kondisi dimana solusi yang dihasilkan bersifat unik.

2. Alternative Optimal Solution, merupakan kondisi dimana solusi optimal yang dihasilkan terdapat beberapa pilihan dan tidak terbatas.

3. Infeasible Solution, merupakan kondisi dimana tidak ada solusi yang dihasilkan yang sesuai dengan fungsi tujuan.

4. Unbounded Solution, merupakan kondisi dimana solusi yang dihasilkan mempunyai ruang solusi yang tidak terbatas, kasus seperti ini biasanya ditemui pada kasus persoalan maksimasi.

\section{Hasil dan Pembahasan}

\section{Prosedur materi model pembelajaran Linear Programming metode grafik}

Program linear metode grafik adalah materi pemecahan persoalan pengalokasian sumber-sumber terbatas diantara aktivitas bersaing. Dalam pemecahan masalahnya program linear mempunyai tahapan-tahapan penyelesainya sehingga cocok dengan model pembelajaran little step. Tahap analisis mencakup analisis diagram pohon pengetahuan (kontruksi materi), pembuatan tangga materi, dan road map materi Program Linear metode grafik.

Kontruksi materi berbentuk diagram pohon pengetahuan. Diagram pohon adalah ilmu pengetahuan yang digambarkan seperti pohon dan merupakan cara untuk menggambarkan sifat dari sebuah struktur secara hirarki dalam bentuk grafik.

Duffy (2012) menyatakan tree diagram merupakan suatu alat generik yang dapat diadaptasikan untuk berbagai maksud yang luas diantaranya:

1. Mengembangkan langkah-langkah logis untuk mencapai hasil yang spesifik.

2. Melakukan analisis five whys dalam mengeksplorasi penyebab.

3. Mengkomunikasikan untuk mendorong keterlibatan dalam pengembangan hasil yang didukung bersama.

4. Menggali pada level yang lebih rinci suatu alur proses.

5. Menggambarkan secara grafik suatu perkembangan hirarkis, seperti silsilah atau skema klasifikasi.

\section{Langkah-Langkah dalam penyusunan pohon masalah [ASM13] :}

Pohon masalah dibuat dengan cara menempatkan masalah utama pada titik sentral atau di tengah gambar. Selanjutnya, penyebab munculnya persoalan tersebut ditempatkan dibagian bawahnya (alur ke bawah) dan akibat dari masalah utama ditempatkan di bagian atasnya (alur ke atas). 


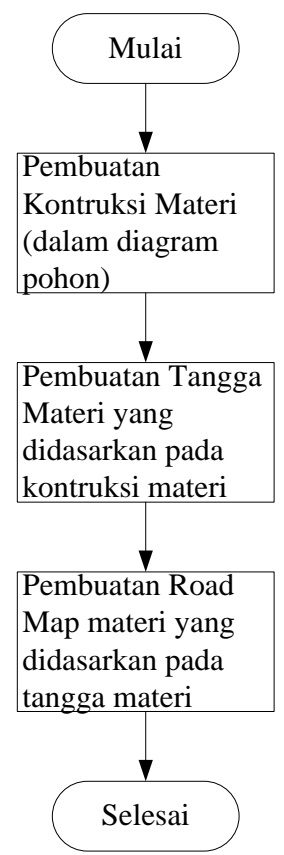

Gambar 2. Tahapan Analisis kebutuhan materi

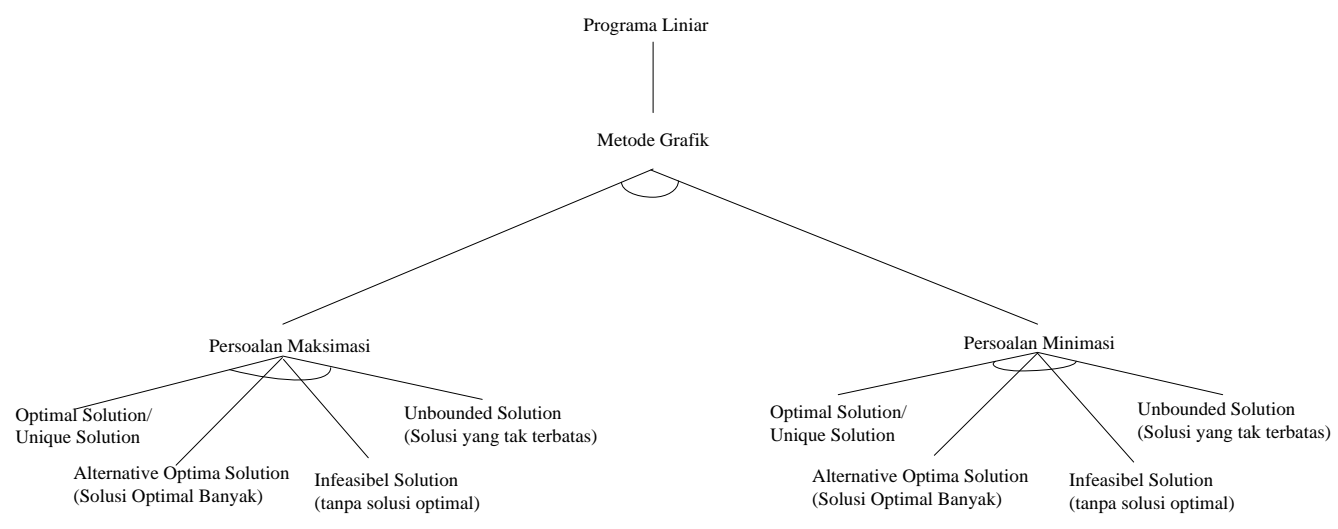

Gambar 3. Diagram Pohon Pengetahuan materi linear programming metode grafik

\section{Tangga Materi}

Analisis tangga materi ini didasarkan dari diagram pohon pengetahuan yang telah dianalisis sebelumnya dan digambarkan pada diagram pohon pengetahuan. Bagian materi Pemrograman linear yang akan diterapkan dalam pembahasan ini adalah Pemrograman Linear metode grafik dan turunannya. Tangga materi ini berfungsi untuk menentukan roadmap materi pemrograman linear metode grafik. Berikut Tangga materi teknik pemecahan Pemrograman Linear untuk lembar kerja little step. 


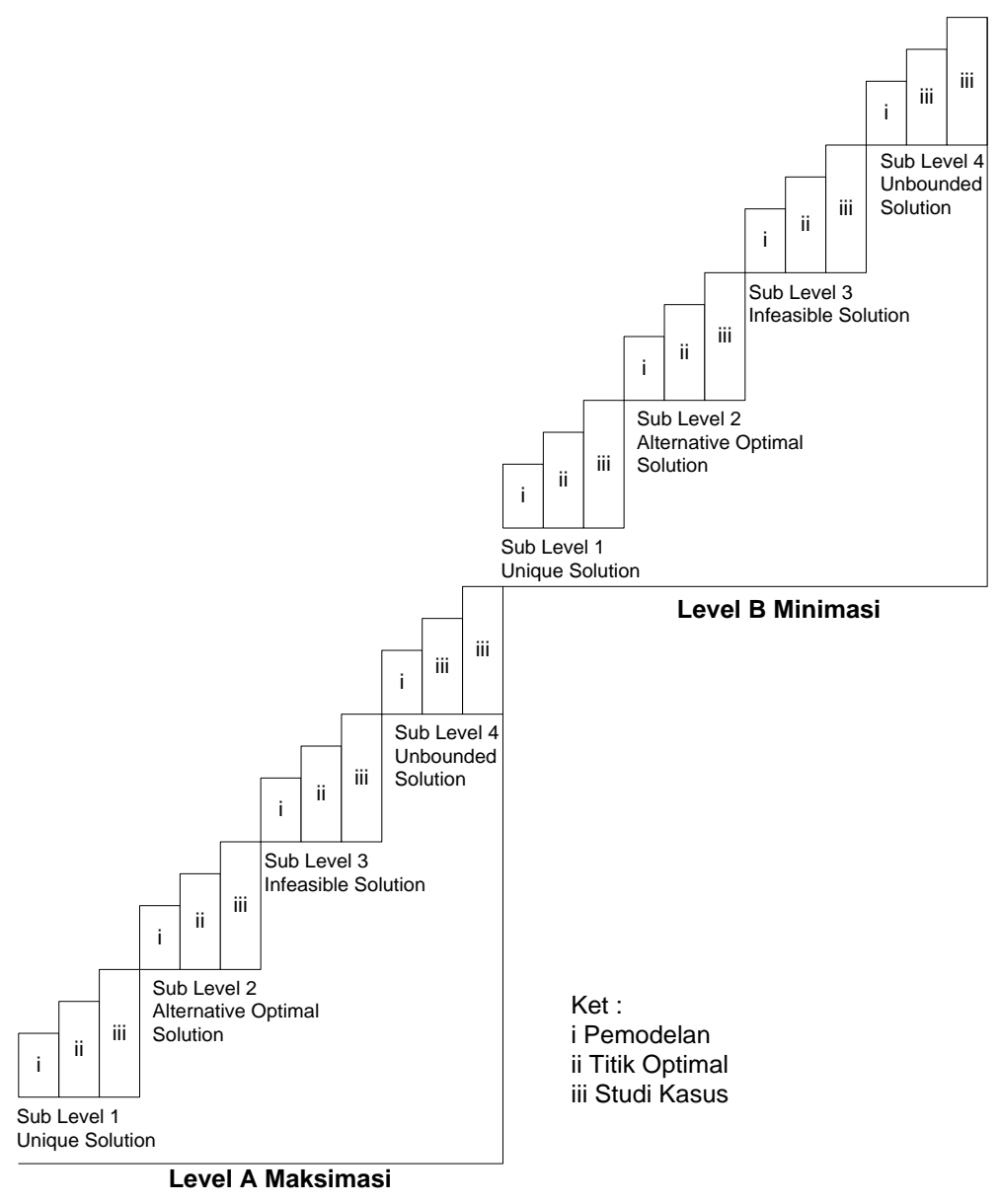

Gambar 4. Tangga Materi Teknik pemecahan Pemrograman Linear untuk lembar

kerja little step

\section{Road Map}

Road map yang akan dibuat mengacu pada tangga materi materi Linear Programming yang telah dianalisis sebelumnya. Road map ini dibutuhkan untuk merancang bahan ajar dan lembar kerja little step pemrograman linear metode grafik, road map materi Liniaer Programming dibuat untuk memfokuskan bahan materi apa saja yang akan disampaikan atau dipelajari oleh peserta didik. Berikut adalah road map materi pemrograman linear metode grafik: 
Tabel 1. Road map pembelajaran teknik pemecahan program linear metode grafik

\begin{tabular}{|c|l|}
\hline \multicolumn{2}{|c|}{ Persoalan } \\
\hline No & \multicolumn{1}{|c|}{ Level A: Maksismasi } \\
\hline 1 & Optimal Solution/Unique Solution \\
\hline 2 & Alternative Optima Solution(Solusi Optimal Banyak) \\
\hline 3 & Infeasibel Solution (tanpa solusi optimal) \\
\hline 4 & Unbounded Solution (Solusi yang tak terbatas) \\
\hline \multicolumn{2}{|c|}{ Level B: Minimasi } \\
\hline 1 & Optimal Solution/Unique Solution \\
\hline 2 & Alternative Optima Solution(Solusi Optimal Banyak) \\
\hline 3 & Infeasibel Solution (tanpa Solusi optimal) \\
\hline 4 & Unbounded Solution (Solusi yang tak terbatas) \\
\hline
\end{tabular}

\section{Lembar Kerja}

Lembar kerja Little Step dilihat dari step (langkah), dibagi menjadi tiga kategori yaitu step kategori dasar, step kategori menengah, step kategori tinggi.

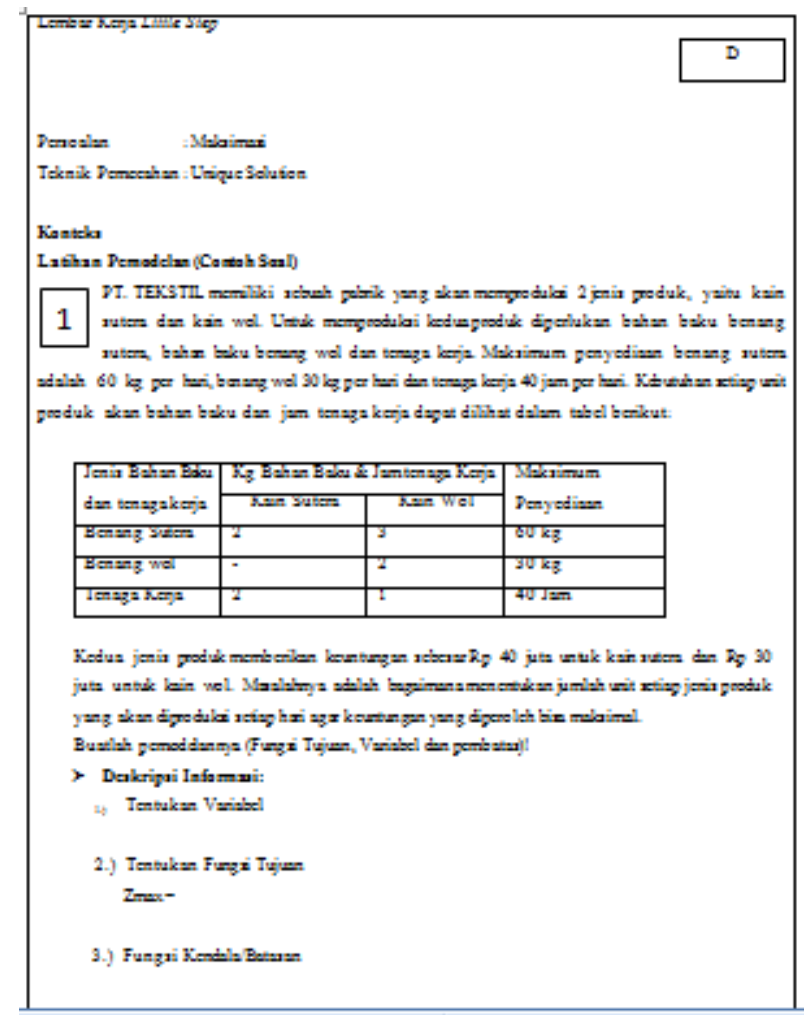

Gambar 5. Rancangan Lembar Kerja Little Step step kategori Dasar 


\section{Perangkat lunak pembantu proses belajar mengajar model pembelajarn Little Step}

\section{Demakalah Proses Bisnis}

Sistem pengelolaan lembar kerja merupakan wadah sharing informasi, sharing materi pembelajaran, sharing lembar kerja. Sistem pengelolaan lembar kerja ini dikelola oleh admin dan dosen. Admin, dosen dan mahasiswa berperan sebagai business actor.

Berikut merupakan gambaran dari business usecase diagram dari pengelolaan lembar kerja :

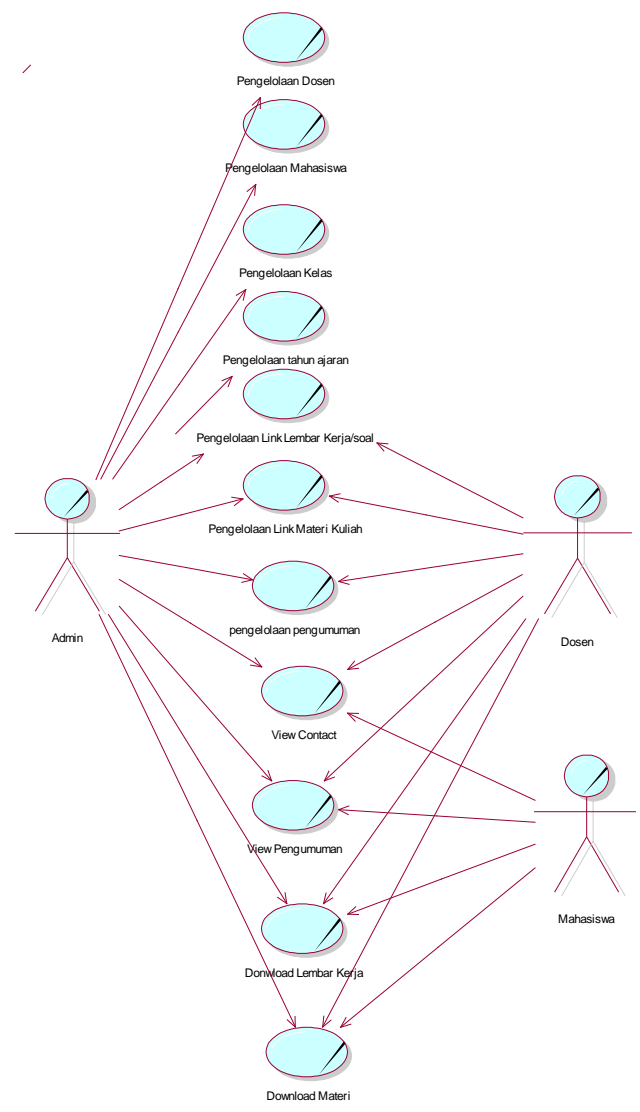

Gambar 6. Business Usecase Diagram

\section{Demakalah Perangkat Lunak}

Perangkat Lunak pembantu model pembelajaran Little Step adalah perangkat lunak yang berfungsi sebagai media sharing informasi, sharing materi pembelajaran, sharing lembar kerja, dan wadah bertanya dengan dosennya. Perangkat lunak pembantu model pembelajaran Little Step ini mempunyai 3 jenis pengguna yaitu Admin, dosen, dan mahasiswa. Pengelola Perangkat Lunak ini yaitu admin dan dosen. Admin berperan sebagai pengelola kesulurahan dari web, dimulai dari pengelolaan tambah, edit, hapus data dosen, mahasiswa, hingga pada pengelolaan upload, download, materi dan lembar kerja, hingga kelola 
pengumuman. Sedangkan dosen berperan sebagai pengelola yang mempunyai otoritas untuk kelola upload,download materi dan lembar kerja, tambah, edit, hapus nilai hingga kelola pengumuman. Otoritas mahasiswa sendiri adalah dapat mendownload materi dan lembar kerja yang sesuai dengan matakuliah yang dikontraknya, selain itu terdapat fasilitas view contact, yang berfungsi untu melihat contact email dosen. Pengumuman hasil evaluasi dari materi dapat dilihatnnya di menu pengumuman.

\section{Lingkup dan Tujuan Perangkat Lunak}

Lingkup dari perangkat lunak ini adalah menangani pengelolaan Link Materi, pengelolaan Link Lembar Kerja yang berguna untuk mahasiswa mendownload materi-materi yang diperlukan dan lembar kerja yang ditugaskan, selain itu perankat lunak dapat menangani pengelolaan pengumuman seperti pengumuman progress report mahasiswa selama mengikuti matakuliah proggress report tersebut terdapat pengelolaan skor dan status(lulus atau mengulang) mahasiswa.

Sedangkan tujuannya adalah mempermudah dosen dalam mengelola nilai dan dapat membantu melihat pemahaman dan penguasaan materi oleh mahasiswa. Selain itu dapat membantu mengadakan kelas (kelas virtual) tanpa harus datang ke kelas nyata.

Hal ini tentu mampu meningkatkan efesiensi waktu dalam memberikan progress report sekaligus mempermudah mahasiswa dalam melihat kemajuan belajar masing-masing. Selain itu, perangkat lunak ini juga memudahkan mahasiswa untuk belajar mandiri.

\section{Perancangan Basis Data}

\section{Entity Relationship Diagram (ERD)}

Data-data yang dikelola oleh perangkat lunak pembantu model pembelajarn Little Step disimpan ke dalam database. struktur tabel dalam basis data didasarkan dari Entity relationship Diagram(ERD).

\section{Rancangan Antar Muka Perangkat Lunak}

Rancangan antar muka perangkat lunak adalah rancangan awal sebuah perangkat lunak yang digunakan sebagai interaksi antara pengguna dan perangkat lunak. Berikut merupakan rancarngan antar muka yang akan dibangun pada perangkat lunak pembantu proses belajar mengajar model pembelajaran Little Step.

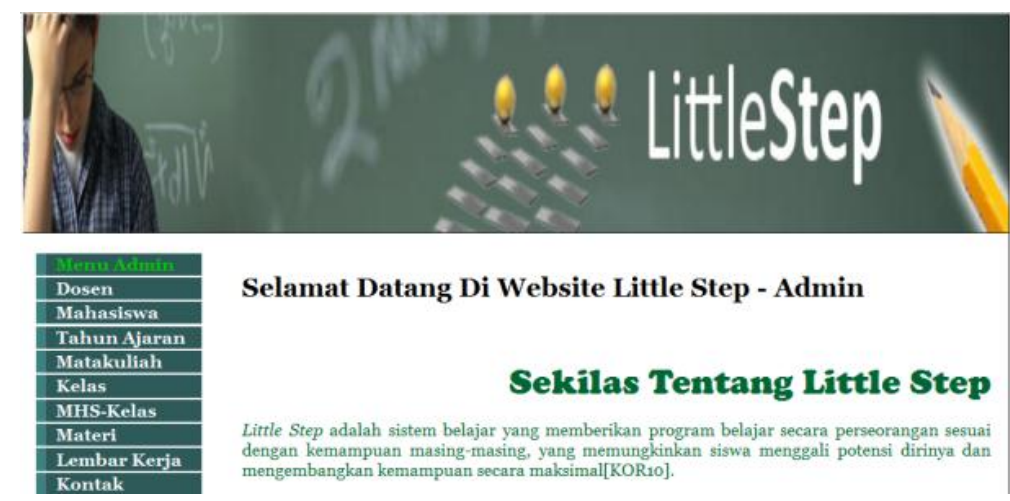




\section{Gambar 8. Menu Admin}

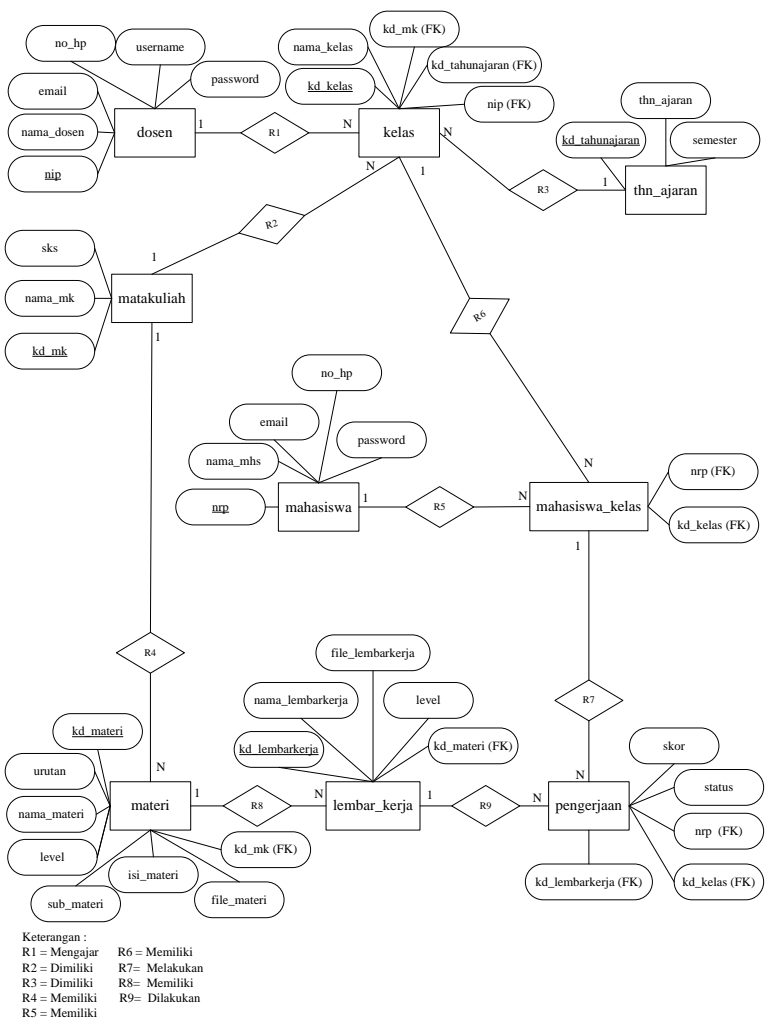

Gambar 7. ERD Perangkat Lunak pembantu Little Step

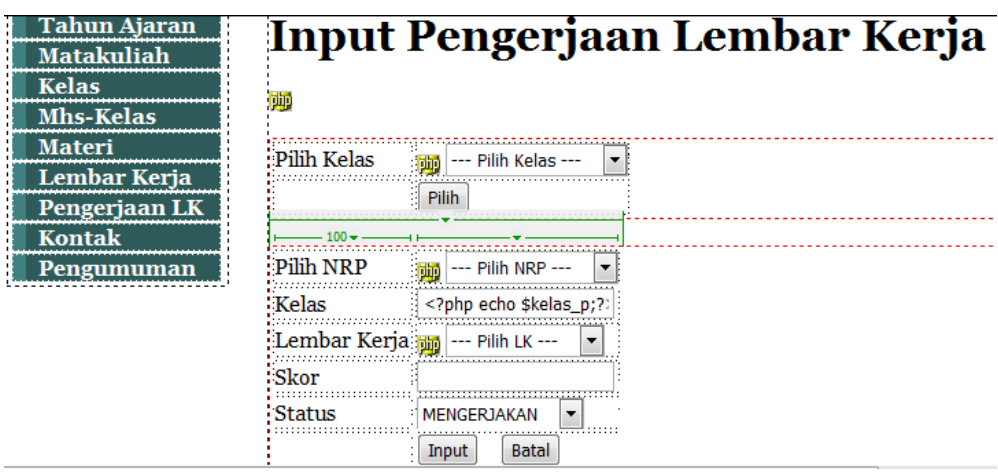

Gambar 9. Halaman pengelolaan pengumuman

Untuk melihat efektifitas lembar kerja, maka dilakukanlah pengujian Peserta uji adalah mahasiswa Jurusan Teknik Informatika UNPAS pada semester pendek matakuliah Penelitian Operasional. Jumlah peserta uji terdapat 19 orang. Pengujian lembar kerja ini bertujuan untuk melihat respon (waktu dan jawaban) 
yang diberikan mahasiswa ketika melakukan uji coba dengan lembar kerja little step serta melihat pemahaman peserta uji dalam pengisian lembar kerja (jawaban terisi dengan sesuai/tidak sesuai). Selain itu juga dapat mengukur kemapuan peserta uji dalam memahami materi Linear programming metode grafik. Kemampuan peserta Uji dapat dilihat dari prosentase jawaban.

\section{Skema Pengujian Lembar Kerja}

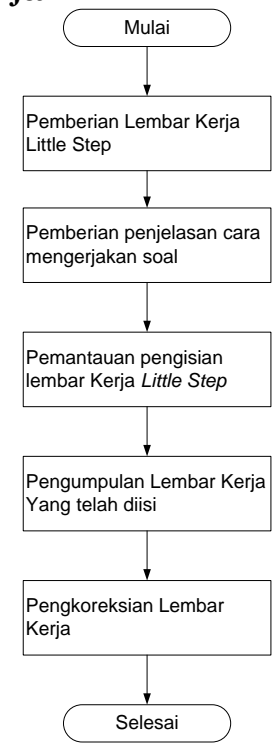

Gambar 10. flow chart realisasi

\section{Materi yang diujikan}

Tabel 2. Road map materi yang diujikan

\begin{tabular}{|c|l|c|c|}
\hline \multicolumn{3}{|c|}{ Persoalan } \\
\hline No & \multicolumn{1}{|c|}{ Level A : Maksismasi } & Sub Level & Step Kategori \\
\hline 1 & Optimal Solution/Unique Solution & 1 & Dasar \\
\hline 2 & Optimal Solution/Unique Solution & 1 & Menengah \\
\hline \multicolumn{2}{|c|}{ Level B : Minimasi } & Sub Level & Step Kategori \\
\hline 1 & Alternative Optima Solution(Solusi Optimal Banyak) & 2 & Menengah \\
\hline 2 & Unbounded Solution (Solusi yang tak terbatas) & 4 & Tinggi \\
\hline
\end{tabular}

\section{Kendala Sample Saat Pengujian}

1. Peserta uji adalah mahasiswa semester pendek, dikarenakan saat pengujian proses belajar mengajar kelas reguler telah berakhir.

2. Peserta uji yang terdaftar dalam kelas semester pendek semula berjumlah 16 orang, saat pengujian bertambah menjadi 19 peserta karena adanya add/drop matakuliah semeter pendek 
3. Dari 19 peserta uji yang mengumpulkan kembali lembar kerja adalah 18 peserta uji dengan alasan lembar kerja tertinggal.

4. Dari 18 peserta uji yang mengumpulkan kembali lembar kerja terdapat beberapa peserta uji yang tidak mengisinya.

Tabel 3. Realisasi materi yang diujikan

\begin{tabular}{|c|l|c|c|}
\hline No & \multicolumn{1}{|c|}{ Soal } & Jumlah Soal & $\begin{array}{c}\text { Jumlah } \\
\text { peserta }\end{array}$ \\
\hline 1 & Level A: Maksimasi - Unique Solution - Dasar & 3 & 5 \\
\hline 2 & Level A : Maksimasi - Unique Solution - Menengah & 3 & 4 \\
\hline 3 & Level B : Minimasi Alternative Optima Solution - Menengah & 3 & 4 \\
\hline 4 & Level B : Minimasi - Unbounded Solution - Tinggi & 3 & 5 \\
\hline
\end{tabular}

\section{Respon Peserta Uji}

Tabel 4. Respon peserta uji pada lembar kerja Kategori Dasar

\begin{tabular}{|c|c|c|c|c|}
\hline $\begin{array}{c}\text { Peserta } \\
\text { Uji }\end{array}$ & Persoalan \& teknik pemecahan & Soal Terisi & $\begin{array}{c}\text { Waktu Yang } \\
\text { dberikan (menit) }\end{array}$ & $\begin{array}{c}\text { Waktu } \\
\text { penyelesain(m } \\
\text { enit) }\end{array}$ \\
\hline 1 & $\begin{array}{c}\text { Level A : Maksimasi - Unique Solution } \\
\text {-Dasar }\end{array}$ & 3 & 60 & 15 \\
\hline 2 & $\begin{array}{l}\text { Level A : Maksimasi - Unique Solution } \\
\text {-Dasar }\end{array}$ & 3 & 60 & 20 \\
\hline 3 & $\begin{array}{l}\text { Level A : Maksimasi - Unique Solution } \\
\text {-Dasar }\end{array}$ & 3 & 60 & 30 \\
\hline 4 & $\begin{array}{l}\text { Level A : Maksimasi - Unique Solution } \\
\text {-Dasar }\end{array}$ & 3 & 60 & 60 \\
\hline 5 & $\begin{array}{l}\text { Level A : Maksimasi - Unique Solution } \\
\text {-Dasar }\end{array}$ & 3 & 60 & 30 \\
\hline
\end{tabular}

Respon dilihat dari waktu pengerjaan lembar kerja, yaitu 155 menit. Rata-rata waktu pengerjaan 31 menit. Waktu yang disediakan 60 menit denga rata-rata soal terisi 3.

\section{Pemahaman Peserta Uji dalam pengujian lembar kerja}

Berikut digambarkan pemahaman dari peserta uji dalam pengisian lembar kerja Little Step. Pemahaman peserta uji berdasarkan step kategorinya dan kesusuain terisinya jawaban akan dipaparkan dengan tabel dan digambarkan dengan grafik. 
Tabel 5. Kesesuaian Pengisian Lembar kerja kategori dasar

\begin{tabular}{|c|c|c|c|}
\hline \multirow{2}{*}{ Peserta Uji } & \multicolumn{3}{|c|}{ Pemahaman Pengisian Lembar kerja } \\
\cline { 2 - 4 } & Variabel & Fungsi Tujuan & Pembatas \\
\hline 1 & Terisi Sesuai & Terisi Sesuai & Terisi Sesuai \\
\hline 2 & Terisi Sesuai & Terisi Sesuai & Terisi Sesuai \\
\hline 3 & Terisi Sesuai & Terisi Sesuai & Terisi Sesuai \\
\hline 4 & Terisi Sesuai & Terisi Sesuai & Terisi Sesuai \\
\hline 5 & Terisi Sesuai & Terisi Sesuai & Terisi Sesuai \\
\hline
\end{tabular}

Tabel 6. Pemahaman peserta pada pengisian lembar kerja Little Step Kategori Dasar

\begin{tabular}{|c|r|}
\hline Kategori & Dasar \\
\hline Paham & 5 \\
\hline Sedang & 0 \\
\hline Tidak Paham & 0 \\
\hline
\end{tabular}

Dapat disimpulkan bahwa 100\% peserta paham terhadap pengisian lembar kerja.

Kemampuan Peserta memahami materi linear programming metode grafik

Berikut digambarkan kemampuan dari peserta uji dalam memahami materi linear programming dengan menggunakan lembar kerja little step. Kemampuan peserta Uji dapat dilihat dari prosentase(\%).

Tabel 7. Tingkat Kemampuan yang dicapai

\begin{tabular}{|c|l|c|c|c|c|c|}
\hline \multirow{2}{*}{$\begin{array}{c}\text { Peserta } \\
\text { Uji }\end{array}$} & \multicolumn{1}{|c|}{ Persoalan \& Solusi } & \multirow{2}{*}{$\begin{array}{c}\text { Soal } \\
\text { Terisi }\end{array}$} & $\begin{array}{c}\text { Benar } \\
(\%)\end{array}$ & $\begin{array}{c}\text { Salah } \\
(\%)\end{array}$ & $\begin{array}{c}\text { Waktu yang } \\
\text { diberikan } \\
\text { (menit) }\end{array}$ & $\begin{array}{c}\text { Waktu } \\
\text { Penyelesain } \\
\text { (menit) }\end{array}$ \\
\hline 1 & $\begin{array}{l}\text { Level A : Maksimasi - Unique } \\
\text { Solution - Dasar }\end{array}$ & 3 & 70,5 & 29,5 & 60 & 15 \\
\hline 2 & $\begin{array}{l}\text { Level A : Maksimasi - Unique } \\
\text { Solution - Dasar }\end{array}$ & 3 & 70,5 & 29,5 & 60 & 20 \\
\hline 3 & $\begin{array}{l}\text { Level A : Maksimasi - Unique } \\
\text { Solution - Dasar }\end{array}$ & 3 & 70,7 & 29,3 & 60 & 30 \\
\hline 4 & $\begin{array}{l}\text { Level A : Maksimasi - Unique } \\
\text { Solution - Dasar }\end{array}$ & 3 & 80,9 & 19,1 & 60 & 60 \\
\hline 5 & $\begin{array}{l}\text { Level A : Maksimasi - Unique } \\
\text { Solution - Dasar }\end{array}$ & 3 & 81,6 & 18,4 & 60 & 30 \\
\hline
\end{tabular}

\section{Kesimpulan pengujian}

Rancangan tersebut diujikan terhadap peserta uji yang mengambil matakuliah Penilitian Operasional materi Linear Programming metode grafik. Respon peserta uji dillihat dari sisi waktu dan jawaban dalam mengerjakan lembar kerja Little Step adalah waktu pengerjaan lebih cepat dari yang disediakan dan soal yang disediakan dapat terjawab. Komentar peserta uji terhadap lembar kerja yaitu langkah-langkah pengerjaan yang disediakan dapat membantu dalam pengerjaan. Pemahaman peserta uji ditinjau dari sisi kesesuainnya bahwa peserta uji memahami langkahlangkah pengerjaan dan cara pengisiannya. Kemampuan peserta uji dalam memahami materi linear programming peserta uji belum memenuhi standar. 


\section{Simpulan}

Rancangan model pembelajaran Littlestep yang dibuat, seperti pembuatan diagram pohon pengetahun, tangga materi, road map pembelajaran materi Linear Programming dalam pemecahan persoalan linear programming menggunakan metode grafik. Road map tersebut dapat dijadikan acuan untuk pembelajaran materi linear programming metode grafik, rancangan model pembelajaran ini menghasilkan lembar kerja materi pembelajaran Linear Programming metode grafik yang dibuat secara Little Step. Dari analisis yang telah dilakukan maka dirancang perangkat lunak untuk menunjang proses belajar mengajar model pembelajaran Little Step yang berfungsi sebagai media berbagi informasi, mengunggah materi, mengunggah lembar kerja, kontak dan pengumuman laporan perkembangan mahasiswa berdasarkan pencapaian masing-masing mahasiswa.

\section{Daftar Pustaka}

1. Asmoko, Hindri., 2012. Memahami Analisis Pohon Masalah. Balai Diklat Kepemimpinan, Pusdiklat Pengembangan SDM, BPPK, Magelang.

2. Cynthia, Riche., 2013. Strategi Pembelajaran. UPI, Bandung.

3. Dimyati T. Tjuju, Dimyati Ahmad., 1992. Operations Research, Model-model Pengambilan Keputusan. Sinar Baru Algesindo, Bandung.

4. Duffy, Gace L., Scott A. Laman, Pradip Mehta, Goving Ramu, Natalia Scriabina,dan Keith Wagoner., 2013. Beyond The Basics: Seven New Quality Tools Help Innovate, Communicate, and Plan.

Http:/www.Asqqm.org/resourcesmodule/download_resource/id/881/,2012.

5. Asyhar Falakhu., 2012. 16 Macam Metode Pembelajaran.

6. Korina Ida., 2010. Penerapan Strategi Pembelajaran Little Step Untuk Penguasaan Materi SQL. Teknik Informatika UNPAS, Bandung.

7. Kustiawan Dadi., 2011. Pengembangan Materi untuk Pembelajaran SQL Dengan Strategi Pembelajaran Little Step. Teknik Informatika Unpas, Bandung.

8. Makmun Abin Syamsuddin., 2003. Psikologi Pendidikan, Rosda Karya Remaja, Bandung.

9. Rufi'i., 2012. Analisis Butir Tes. PPS UNIPA, Surabaya.

10. Rumate, Frans A., 2005. Pendekatan Konstruktivisme Dalam Pembelajaran. Bagian Kegiatan Peningkatan Kualitas Sumber Daya Manusia Dirjen Dikti, Dirjen Dikti.

11. Senjaya Wina, 2008. Strategi Pembelajaran; Berorientasi Standar Proses Pendidikan. Kencana Prenada Media Group, Jakarta.

12. Sudrajat.,2008. Pendahuluan Penelitian Operasional: Modul 1. Matematika UNPAD, Bandung. 
Vina Anggraeni et al / JMI Vol 9 No 1 April 2013, pp 75 - 89 